\title{
Vertical distribution, segregation by size and recruitment of the yellow clam Mesodesma mactroides Deshayes, 1854 (Mollusca, Bivalvia, Mesodesmatidae) in exposed sandy beaches of the Rio Grande do Sul state, Brazil
}

\author{
Bergonci, PEA. * and Thomé, JW. \\ Escritório de Malacologia e de Biofilosofia, \\ Praça Dom Feliciano, 39, sala 1303, ed. Guanabara, centro, CEP 90020-160, Porto Alegre, RS, Brasil \\ *e-mail: paulobergonci@gmail.com \\ Received June 22, 2006 - Accepted September 5, 2006 - Distributed May 31, 2008
}

(With 11 figures)

\begin{abstract}
The vertical distribution and the segregation by size of the yellow clam Mesodesma mactroides Deshayes, 1854 were investigated in the intertidal zone and its limits with the lower and upper shores at exposed sandy beaches of Rio Grande do Sul state, Brazil. The gathering was made throughout 12 months; from the Pinhal beach towards the south of the State, in six $15 \mathrm{~km}$ equidistant transects, determined through random selection. In these transects, the calculation of 30 consecutive waves was made in order to determine its average amplitude point (P0), from which two points were marked towards the lower shore (P-1 and P-2) and three towards the upper shore (P1, P2 and P3). A 30 by $50 \mathrm{~cm}$ cylinder was buried down to the depth of $40 \mathrm{~cm}$, the material was separated with a $0.25 \mathrm{~cm}$ mesh and the specimens were quantified and measured in length. The yellow clam presented segregation by size, especially between recruit and adult individuals, with recruits occupying preferably the zones above P0 and adults from this point towards the sea. The young specimens are distributed through all zones, mixed with adult and recruit specimens, which dismisses the hypothesis of segregation by size in function of competition for space and food, once the burying depth is directly proportional to their length. However, the segregation between recruits and adults might be related to the filtering mechanism of the adults, which could ingest the larva, as well as the fact that the recruits, being small and light, are easily transported to the regions above P0. Seasonal migration was observed for adult individuals during winter and spring, probably associated to the reproduction period of the species, being that the peak of recruitment was greater in the end of the winter and the beginning of spring.
\end{abstract}

Keywords: depth, intertidal, macroinfauna, Mesodesmatidae.

\section{Distribuição vertical, segregação por tamanho e recrutamento do marisco branco Mesodesma mactroides Deshayes, 1854 (Mollusca, Bivalvia, Mesodesmatidae) em praia arenosa exposta do Rio Grande do Sul, Brasil}

\begin{abstract}
Resumo
Foram investigadas a distribuição vertical e a segregação por tamanho no marisco branco Mesodesma mactroides Deshayes, 1854 na zona intermareal e seu limite com o infra e o supralitoral nas praias arenosas expostas do Rio Grande do Sul, Brasil. Ao longo de 12 meses, foram realizadas as coletas a partir da praia de Pinhal em direção ao sul do Estado, em seis transectos eqüidistantes $15 \mathrm{~km}$, determinados mediante sorteio. Nestes, procedeu-se ao cálculo de 30 ondas consecutivas para avaliar o seu ponto médio de amplitude (P0), a partir do qual, foram assinalados dois pontos em direção ao infralitoral (P-1 e P-2) e três em direção ao supralitoral (P1, P2 e P3). Enterrou-se um cilindro de $30 \times 50 \mathrm{~cm}$ até $40 \mathrm{~cm}$ de profundidade, sendo o material triado em malha de $0,25 \mathrm{~cm}$ com os exemplares quantificados e mensurados em comprimento. O marisco branco apresentou segregação por tamanho, em especial entre os indivíduos recrutas e os adultos, com os recrutas ocupando preferencialmente as zonas acima de P0 e os adultos, deste ponto em direção ao mar. Já os jovens estão distribuídos por todas as zonas, mesclados com os espécimes adultos e com os recrutas, o que descarta a hipótese de segregação por tamanho em função da competição por espaço e por alimento, uma vez que a profundidade em que se enterram é diretamente proporcional ao seu comprimento. Já a segregação entre os indivíduos recrutas e adultos, pode estar relacionada ao mecanismo de filtração dos adultos, que poderiam ingerir as larvas, como também, ao fato de que os recrutas, por serem pequenos e leves, são facilmente transportados para as regiões acima de P0. Foi constatada a migração sazonal por parte dos indivíduos adultos no inverno e na primavera,
\end{abstract}


provavelmente associada, ao período de reprodução da espécie, pois o pico de recrutamento mais pronunciado foi no fim do inverno e no início da primavera.

Palavras-chave: profundidade, intermareal, macroinfauna, Mesodesmatidae.

\section{Introduction}

The exposed sandy beaches are classified as dissipative, favoring the occurrence of an abundant and diverse macroinfauna which is characterized by following a zonation pattern (Gianuca, 1987). MacLachlan (1990) affirms that theses beaches are, among all marine ecosystems, the environments mostly controlled by physical factors, which determine the distribution patterns of the animals. In this concept, Borzone and Souza (1997) point out that the stability of the sediment is more intimately connected to the zonation process than to the levels reached by the tides. McLachlan and Jaramillo (1995) and Brazeiro and Defeo (1996) cite that the constant dislocation of the swash zone and the seasonal alterations make the vertical distribution less defined and more variable than in other types of beaches, where the organisms constantly change their position on the beach. For these reasons, Brazeiro and Defeo (1996) believe that it is not possible to establish rigid patterns of zonation at sandy beaches. Various zonation schemes for organisms at sandy beaches were proposed, such as Dahl (1952), based on the distribution of crustaceans on many beaches of the world, and Salvat (1964), delimitating the zones according to the moisture gradient of the sediment.

For the macroinfauna of the beaches of southern Brazil, Gianuca $(1983 ; 1987)$ made a scheme of the zonation as follows: one upper shore zone, one denominated mesolitoral or intertidal (where the swash zone is located) and internal and external breaking zones (lower shore). Among the zones cited by Gianuca (1987), the mesolitoral stands out, being a very extense zone where the majority of the residing species show a vertical distribution pattern limited by the sea water level and by the alterations on the profile of the beach. It is also the zone with the greatest biomass concentration of macroinfauna, especially benthic invertebrates (Escofet et al., 1979; Gianuca, 1985), where, in terms of biomass, the bivalves are dominant (Gianuca, 1983; Brazeiro and Defeo, 1996). Such dominium in biomass is due to the presence of the Mesodesma mactroides Deshayes, 1854, precisely because it presents a vertical distribution considerably wider than the other existing organisms (Gianuca, 1983). M. mactroides is popularly known as the yellow clam, and is a suspension-feeding filtrating bivalve, typical to the intertidal zone of sandy beaches, distributed from Ilha Grande, in the Rio de Janeiro, Brazil to the Bahia Blanca, in Argentina (Rios, 1994).

The goal of this work was to verify the existence of segregation by size, as well as the existence of seasonality in the vertical distribution of the yellow clam in the intertidal zone and its limits with the upper and lower shores at the exposed sandy beaches of the Rio Grande do Sul, Brazil.

\section{Material and Methods}

\subsection{Description of the study area}

The littoral of the Rio Grande do Sul (RS) comprehends a littoral zone from Torres to the Chuí, constituted by low and sandy soils, with great lagoons and flooded terrains, and smooth topography (Villwock, 1987), comprehending approximately $660 \mathrm{~km}$ of uninterrupted exposed beaches (Tomazelli and Villwock, 1992). These beaches present a practically straight configuration, without large intermissions or irregularities, which gives it an open characteristic, with beaches exposed to the action of medium and high energy waves, being characterized as exposed (Villwock, 1987) and dissipative (Gianuca, 1987).

The study was developed in approximately 85 of the $660 \mathrm{~km}$ of these exposed beaches, embracing the littoral comprehended between the municipalities of Pinhal ( $30^{\circ} 15^{\prime} 35^{\prime \prime} \mathrm{S}$ and $50^{\circ} 14^{\prime} 01,9$, ' W) and São Simão $\left(30^{\circ} 58^{\prime} 32,8^{\prime \prime} \mathrm{S}\right.$ and $50^{\circ} 40^{\prime} 39,5^{\prime \prime} \mathrm{W}$ ) (Figure 1).

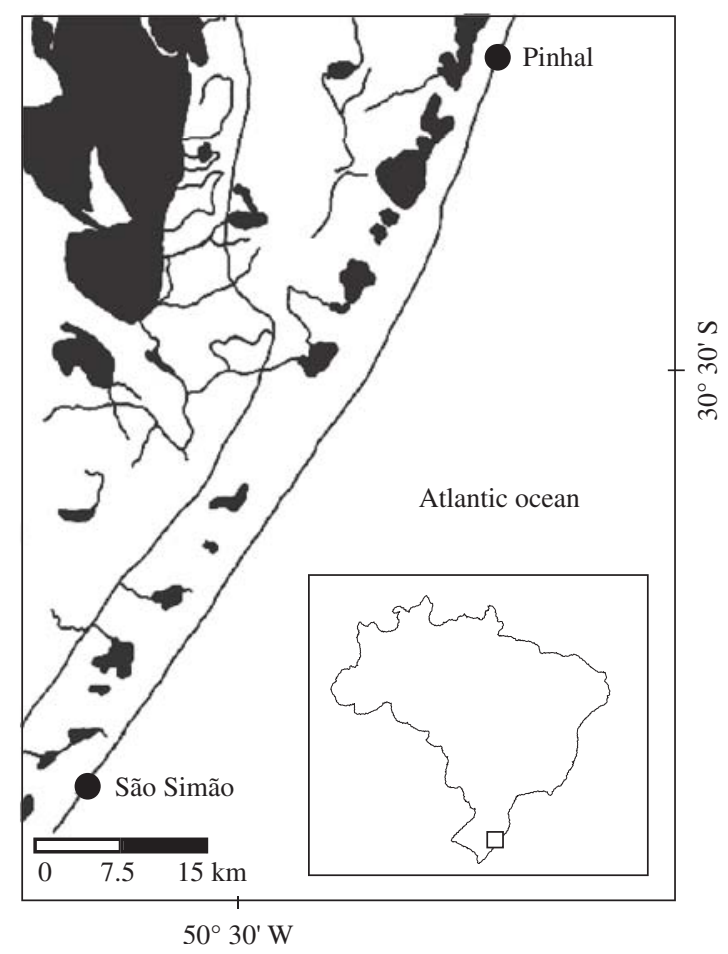

Figure 1. Map of study area. 
The littoral zones, in which the sample units were made, are characterized according to the faunal distribution proposed by Gianuca (1987).

\subsection{Gathering and laboratory methodology}

The samples were made on a monthly basis, starting in the beginning of October of 2004 and ending in September of 2005. According to Coscarón (1959), Olivier and Penchaszadeh (1968) and Gianuca (1983; 1987), the populations of yellow clam occur from the upper mesolitoral to the limits of the lower mesolitoral with the lower shore, passing through the swash zone. Among the habitats referred by Gianuca (1987), the gatherings were developed in the zones where the presence of $M$. mactroides occurs, being the mesolitoral and its upper and lower limits.

The gatherings were made from the Pinhal beach towards the south of the State, in six transects distant by $15 \mathrm{~km}$ between each other. The first transect was determined randomly among 10 points, equally distant by $1 \mathrm{~km}$ (five points to the north and five to the south), using a permanent and pre-determined place of reference, guaranteeing the randomness of data gathering.

In each transect, the calculation of 30 consecutive waves was made, in order to evaluate the average amplitude point of the waves (P0), being the average point of the swash zone, following the morphodynamism of the beach. From P0, two points were marked towards the lower shore (P-1 and P-2) and three towards the upper shore (P1, P2 and P3), distant with a standard deviation of the average amplitude of the waves (P0), making a total of six points per transect (Silveira, 1998) (Figure 2). In each of the six points, a 30 by $50 \mathrm{~cm}$ cylinder was buried down to the depth of $40 \mathrm{~cm}$, the sediment was extracted and separated using a $0.25 \mathrm{~cm}$ mesh and the organisms fixed in alcohol $70 \%$.

In the laboratory, the counting of these specimens and the measuring of the length (anterior-posterior direction of the shell) were made using a digital Mytutoio caliper rule of $0.01 \mathrm{~mm}$ precision. The animals of up to $10 \mathrm{~mm}$ of length were considered recruits, the ones with lengths between 10 and $43 \mathrm{~mm}$ were considered young, and specimens with lengths above $43 \mathrm{~mm}$ were considered adults, according to Defeo (1998).

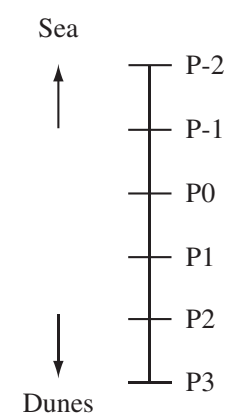

Figure 2. Gathering points scheme.

\subsection{Data analysis}

The vertical distribution was determined through the percentage value of the abundance of gathered specimens in each sampled point, adding the six transects and the respective months of gathering. To verify the existence of seasonality in this distribution, the data was grouped by season of the year.

In order to prove the occurrence of segregation by size, the data was grouped in the same manner as mentioned above, making, for each sample point, the percentage of specimens considered recruits, young and adults. The length average of the individuals on the respective points was also calculated, considering primarily all population components (recruits, young and adults) and secondarily removing the young population from the calculations.

With the objective to facilitate the comprehension of the above mentioned parameters, the data was grouped in three manners: $\mathrm{P}-2+\mathrm{P}-1 ; \mathrm{P} 0+\mathrm{P} 1$; and $\mathrm{P} 2+\mathrm{P} 3$. Such grouping was made after observing that there is no significant difference between the grouped points, obtained through the variance Analysis (ANOVA) followed by multiple comparisons by the Tukei method (Sokal and Rolhf, 1997; Zar, 1999). To verify the existence of significant differences between specimen sizes and the respective grouped points $(\mathrm{P}-2+\mathrm{P}-1 ; \mathrm{P} 0+\mathrm{P} 1$; and $\mathrm{P} 2+3)$, with and without the presence of young individuals, the same above mentioned method was used.

The average length comparisons between different grouped points in the four seasons of the year were made through the covariance analysis (ANCOVA), considering the grouped points and the air and water temperatures as co-variants and the different seasons of the year as a variation factor, using, later, the comparison through the Bonferroni method. Both tests were made with the aid of the statistic package SPSS version 13.0, after transforming the data to natural logarithm (Ln), in order to minimize normality deviations (Sokal and Rolhf, 1997).

\section{Results}

\subsection{Vertical distribution and segregation by size}

The vertical distribution (depth) presented by the yellow clam, considering the percentage of specimens gathered in each point and disconsidering the age (recruit, young and adult), was of $5.02 \%$ at P-2 (limit with lower shore), $14.66 \%$ at $\mathrm{P}-1,20.93 \%$ at $\mathrm{P} 0,24.39 \%$ at $\mathrm{P} 1,29.89 \%$ at $\mathrm{P} 2$ and $5.11 \%$ at P3 (Figure 3). Based on this data, it can be concluded that the most part of the specimens, about $75 \%$, are found at the average point of the swash area (P0), at P1 and P2; at P-1, approximately $15 \%$ of the specimens are found. Together, $\mathrm{P}-2$ and $\mathrm{P} 3$ are $10 \%$ of the total of yellow clam specimens, indicating that the concentration of individuals occurs around the average point of the swash area.

In relation to the segregation by size, the adult individuals were found at the points closest to the limit with the lower shore, with percentage values that vary between 
0 at $\mathrm{P} 3$ to $46.02 \%$ at $\mathrm{P}-1$; at $\mathrm{P}-2$ they represent $41.2 \%$ of the individuals; at $\mathrm{P} 0,37.87 \%$; $1,33.44 \%$; and at $\mathrm{P} 2$, $27.32 \%$, indicating a possible preference for the medium portion of the swash zone and from this zone towards P-2 (including). For recruit specimens, the observed path was practically the opposite of the one presented for adult individuals, where no specimen was gathered at P-2 and only $12.02 \%$ were gathered at $\mathrm{P}-1$. The predominance of recruits occurs at P3, where they constitute $59.41 \%$ of the individuals; at $\mathrm{P} 2,44.10 \%$; and at $\mathrm{P} 0,42.60 \%$. Differently than observed for adult and recruit individuals, the young specimens are scattered through all zones, representing $58.80 \%$ of the individuals gathered at P-2, $41.96 \%$ at $\mathrm{P}-1,41.41 \%$ at $\mathrm{P} 0,23.96 \%$ at $\mathrm{P} 1,28.58 \%$ at $\mathrm{P} 2$, and $40.59 \%$ at $\mathrm{P} 3$ (Figure 4 ).

This data is shown in Figure 5a, where the differences between average specimen sizes in relation to the respective points of vertical distribution can be directly observed. The average shell length values, as well as their standard errors $(\mathrm{mm})$ for each sampled point, were respectively: P-2, $37.12( \pm 3.2)$; $\mathrm{P}-1,38.57( \pm 1.49)$; P0, 32.97 ( \pm 1.37$)$; P1, 30.29 ( \pm 1.37$)$; P2, 28.34 ( \pm 1.28$)$; and P3, $23.46( \pm 2.77)$. Once again, the differences of average size are very clear between the points below (P-2 and P-1) and above (P1, P2 and P3) the average point of the swash zone (P0).

The found results become more evident when the young specimens are withdrawn from Figure 3 (Figure 6), once they are scattered throughout all gathering zones,

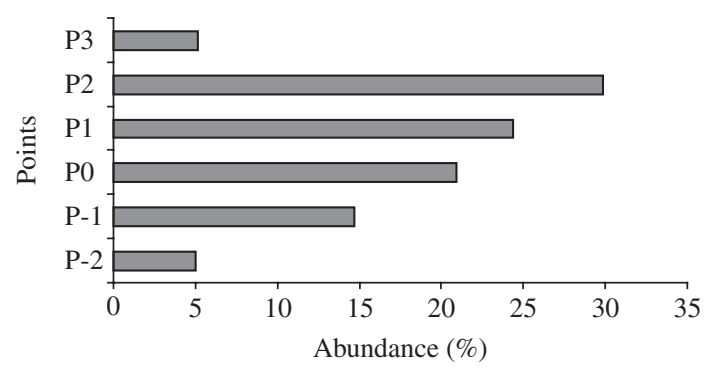

Figure 3. Vertical distribution of $M$. mactroides at exposed sandy beaches of Rio Grande do Sul, Brazil.

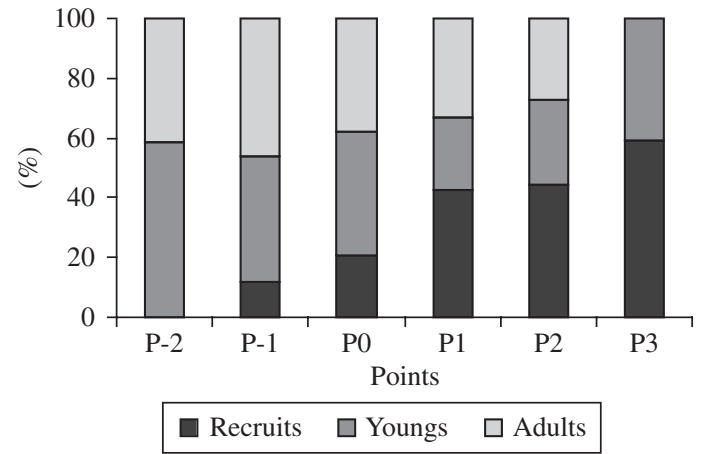

Figure 4. Percentage of recruit, young and adult specimens by sample point. from which a clear differentiation between recruit and adult specimens can be verified. These differences increase when observing the average lengths at these points without the presence of the young specimens: P-2, 57.04 ( \pm 2.21 ); P-1, 48.43 ( \pm 2.15$) ;$ P0, 42.37 ( \pm 2.20$)$; P1, 31.69 ( \pm 1.93$)$; P2, $29.15( \pm 1.98)$; and P3, $26.31( \pm 4.47)$ (Figure 5b).

The results found from the grouping of points $(\mathrm{P}-2+\mathrm{P}-1 ; \mathrm{P} 0+\mathrm{P} 1$; and $\mathrm{P} 2+\mathrm{P} 3)$ confirm the above mentioned questions, where the young individuals make $31.96 \%$ in group $\mathrm{P} 2+\mathrm{P} 3,22.24 \%$ in $\mathrm{P} 0+\mathrm{P} 1$ and only
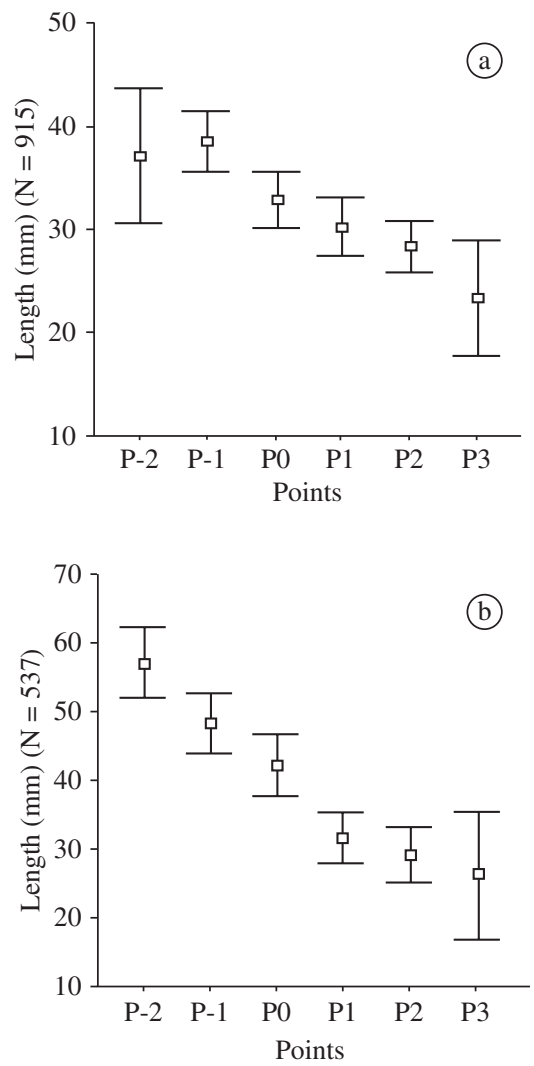

Figure 5. Vertical distribution of M. mactroides, by size, sampled points. a) considering the young population; and b) without young population.

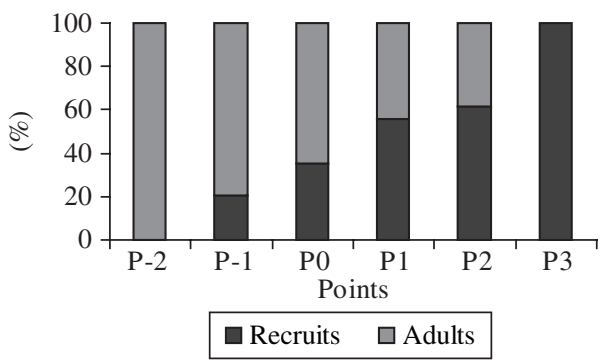

Figure 6. Zonation of $M$. mactroides recruits and adults on the respective gathering points. 
$3.2 \%$ in $\mathrm{P}-2+\mathrm{P}-1$. The adults are $41.27 \%$ in $\mathrm{P}-2+\mathrm{P}-1$, $35.89 \%$ in $\mathrm{P} 0+\mathrm{P} 1$ and $25.62 \%$ in $\mathrm{P} 2+\mathrm{P} 3$. In a more uniform manner, the young made $55.53 \%$ in $\mathrm{P}-2+\mathrm{P}-1$, $41.87 \%$ in $\mathrm{P} 0+\mathrm{P} 1$ and $42.42 \%$ in $\mathrm{P} 2+\mathrm{P} 3$. The average values of shell length $(\mathrm{mm})$ and their respective standard errors, with and without the presence of young individuals, were, respectively: P-2 + P-1, 38.33 $( \pm 1.35)$ and $50.96( \pm 1.79) ; \mathrm{P} 0+\mathrm{P} 1,31.53( \pm 0.97)$ and $36.85( \pm 1.52)$; and P2 + P3, $27.63( \pm 1.17)$ and 29.16 $( \pm 1.84)$ (Figures $7 \mathrm{a}$ and $7 \mathrm{~b}$ ).

The existence of size segregation between the three groups of points, considering the young population, was statistically significant $(\mathrm{Fp}=22.404 ; \mathrm{p}<0.001)$, as well as disconsidering the young population $(\mathrm{Fp}=24.834$; $\mathrm{p}<0.001$ ), confirming the explanations above about size differences between the respective zones of the sampled beach, where the greater size (average) specimens are found in the zones closest to the sea.

\subsection{Seasonal vertical distribution and recruitment}

Concerning the seasonal variations in the vertical distribution of the yellow clam, it is confirmed, from the data on Table 1, that there is an increase in the percentage of individuals from autumn to spring in the direction of the points $\mathrm{P}-1$ and $\mathrm{P}-2$, being from below the average point
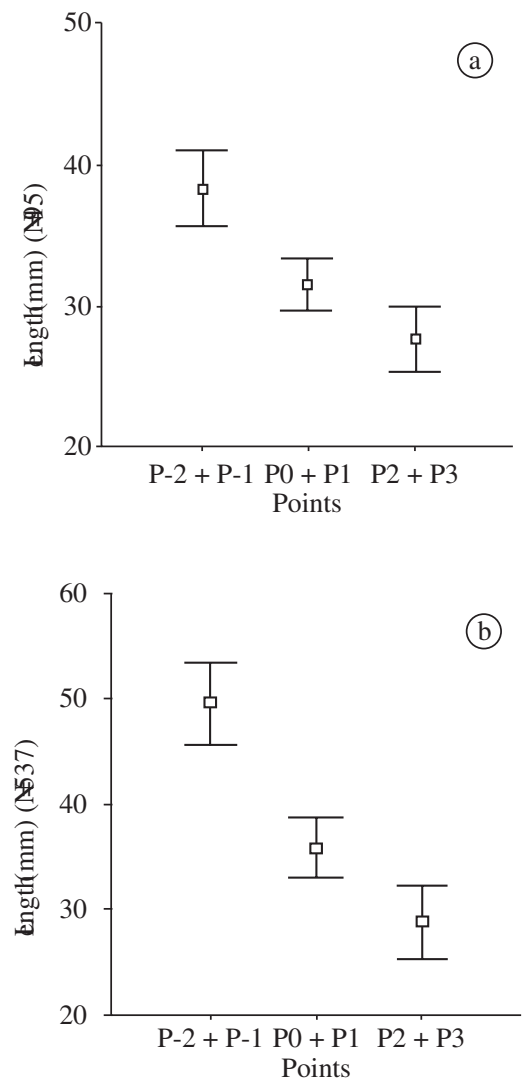

Figure 7. Vertical distribution of M. mactroides, by size, according to grouped points. a) considering the young population; and b) without young population. of the swash zone towards the limit between the lower mesolitoral and the lower shore, with increasing percentage values from autumn to spring and decreasing values for the summer (Figure 8). Observing Figures 9a and b, it is observed that this movement was not only made by specimens that are considered young, but mainly by adult individuals, where, adding both points, the average length presented by the animals was of $38.33 \mathrm{~mm}$ $( \pm 1,34)$ (with young specimens) and $50.96 \mathrm{~mm}$ (without young specimens).

Throughout the four seasons of the year, the average length of the specimens was not constant: autumn, $37.21 \mathrm{~mm}$; winter, $24.15 \mathrm{~mm}$; spring, $13.94 \mathrm{~mm}$; and summer, $44.93 \mathrm{~mm}$.

According to the covariance analysis, using the grouped points and water and air temperatures as covariants and the seasons of the year as a variation source, there are significant differences between the sizes of individuals during the winter and spring, when compared to the specimen sizes during the autumn and summer (Figures 10a and b). It is observed that the average lengths of the winter and spring specimens are smaller than in the other two seasons, probably related to the period of recruitment (Figure 11), which seems to the

Table 1. Percentage of yellow clam population density by gathering point along the seasons of the year and throughout the entire year.

\begin{tabular}{lccccc}
\hline Points & Autumn & Winter & Spring & Summer & Annual \\
\hline P-2 & 0,42 & 7,38 & 11,74 & 0,54 & 5,02 \\
P-1 & 11,30 & 9,734 & 20,43 & 17,17 & 14,66 \\
P0 & 16,32 & 7,38 & 33,04 & 26,98 & 20,93 \\
P1 & 24,27 & 22,48 & 15,65 & 35,15 & 24,39 \\
P2 & 45,61 & 37,92 & 19,13 & 16,89 & 29,89 \\
P3 & 2,09 & 15,1 & 0 & 3,27 & 5,11 \\
Total & 100 & 100 & 100 & 100 & 100 \\
\hline
\end{tabular}

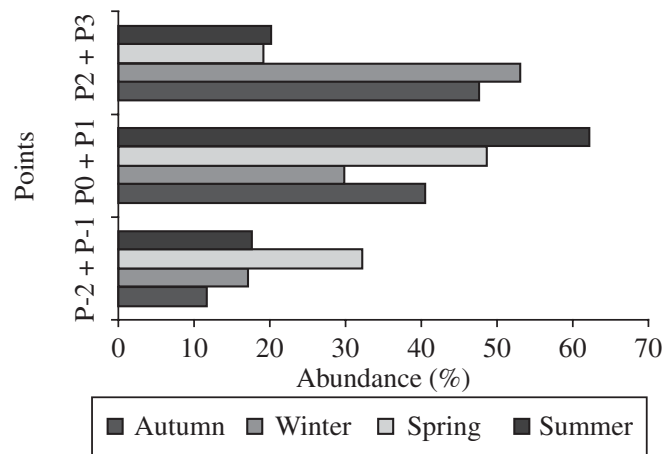

Figure 8. Vertical distribution of $M$. mactroides through seasons of the year and the grouped points. 

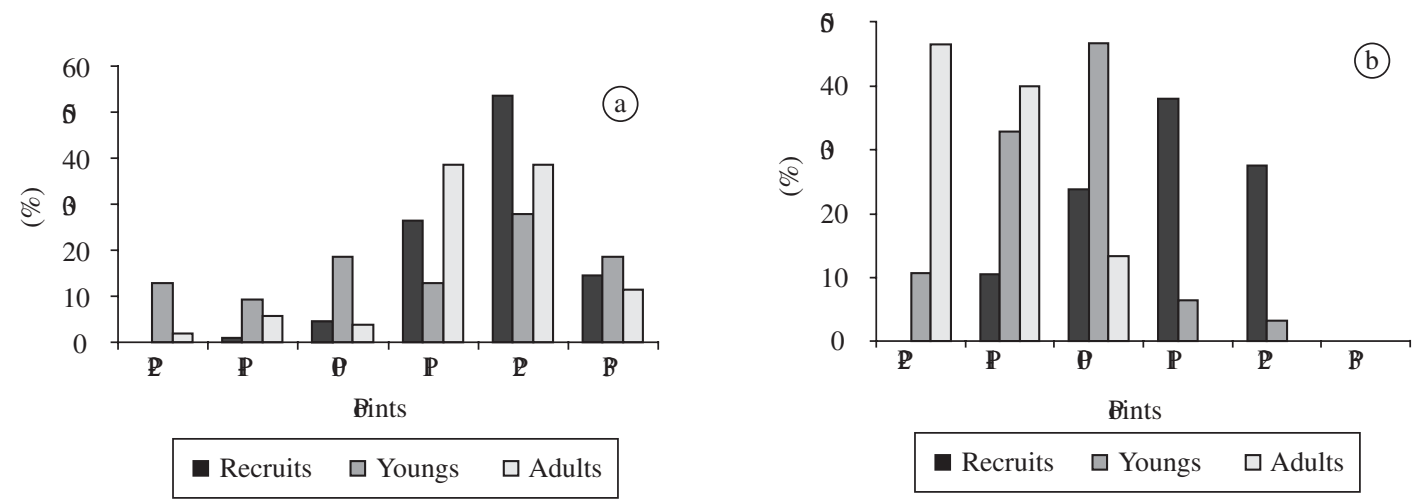

Figure 9. Percentage of M. mactroides recruit, young and adult specimens by gathering point. a) Winter; and b) Spring.
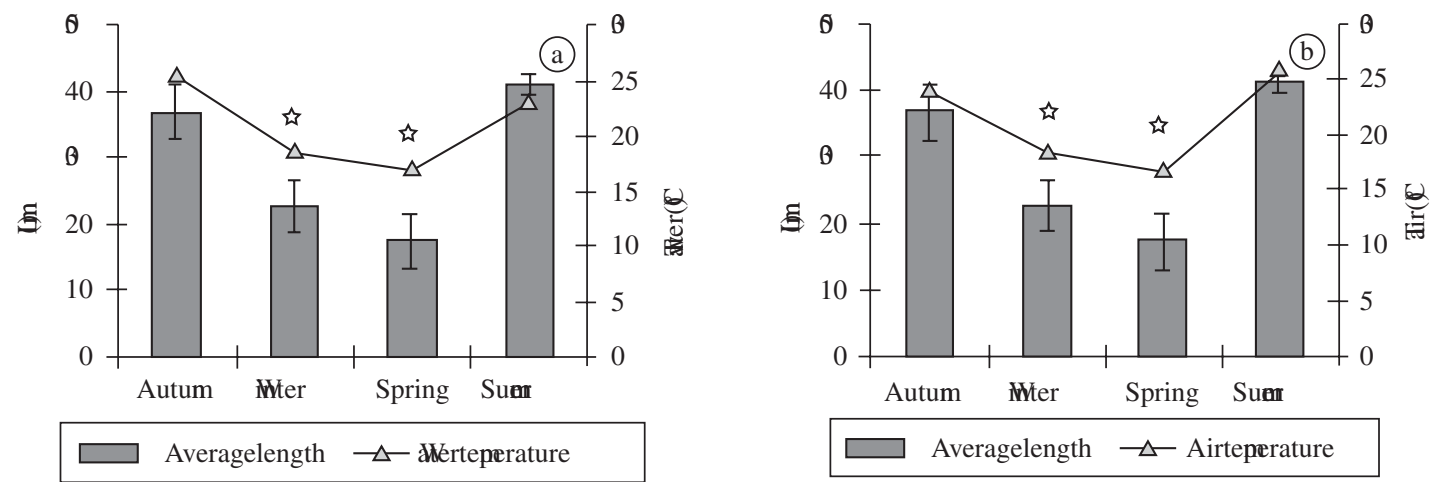

Figure 10. Average length values in the four seasons of the year and respective standard error, a) associated to the temperatures of water; and $\mathrm{b}$ ) air. The asterisk indicates significant difference according to the ANCOVA results ( $\mathrm{a}$ : $\mathrm{Fp}=23.83$, $\mathrm{p}<0,001 ; \mathrm{b}: \mathrm{Fp}=8,98, \mathrm{p}<0,001)$.

associated to low temperatures (Figures 10a and b). The averages of air and water temperatures, as well as their respective standard errors, for the four seasons of the year were, respectively: autumn, $23.81{ }^{\circ} \mathrm{C}( \pm 0.39)$ and 25.25 ( \pm 1.56$)$; winter, $18.35( \pm 1.64)$ and $18.45( \pm 0.84)$; spring, $16.59( \pm 0.91)$ and $16.88( \pm 1.37)$; and summer, $25.75( \pm 1.87)$ and $22.90( \pm 1.67)$.

Concerning the recruitment period, two peaks were observed, one intense in the month of August, with recruits representing about $82 \%$ of the total of captured individuals, and another of smaller intensity in November, representing approximately $37 \%$ of the specimens. The beginning of recruitment occurred in July $(\sim 24 \%)$, extending through the months of August (most intense peak), September and October. In November ( 37\%), there was another recruitment peak which extended to February of 2005. Specimens lower than $10 \mathrm{~mm}$ were not found in the months of April and June, being that in March they represented less than $1 \%$ of the gathered yellow clam (Figure 11).

\section{Discussion}

In this study, the yellow clam $M$. mactroides presented segregation by size, especially between recruit

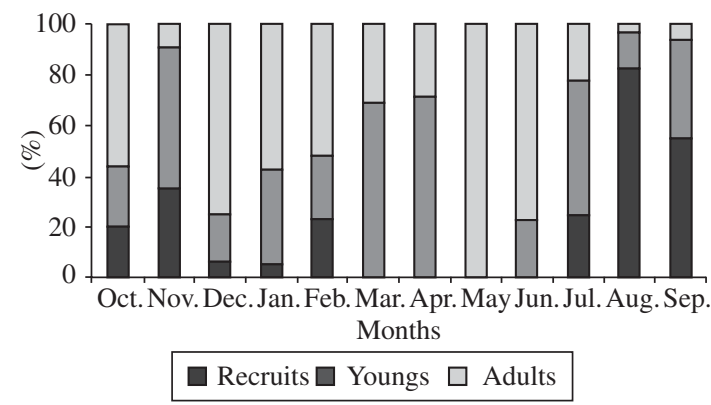

Figure 11. Proportion of recruit, young and adult specimens throughout the months.

and adult individuals, with recruits occupying preferably the zones above the average point of the swash zone and the adults occupying from this point towards the sea. The young individuals are distributed throughout all zones, mixed with adult and recruit specimens.

The results found in this study are different than those observed by Gianuca (1985) at the Cassino beach (RS, Brazil) and by Coscarón (1959) at the coast of the Buenos Aires province (Argentina), where the adult 
specimens were found above the swash zone (upper mesolitoral), and the young and recruits were considered sea migrates, which was not verified in this study, being that the young are scattered throughout all regions of the intertidal zone and the recruits are mainly in the limit of this region with the upper shore.

When compared to other Mesodesmatidae, such as M. donacium (Lamarck 1818), Paphies ventricosa (Gray, 1843), P. subtriangulata (Wood, 1828) and P. donacina (Spengler, 1793), the results are similar, once that for all the species, concerning segregation by size, the larger specimens are found from the limit of the mesolitoral with the lower shore. The young of these species are scattered throughout the swash zone and limits of the mesolitoral with the upper shore, also being occasionally found with large individuals. (McLachlan et al., 1996). Gil and Thomé (2000; 2001), when studying the malacofauna at the Arroio Teixeira beach (RS, Brazil), mention that the M. mactroides and Donax hanleyanus (Philippi, 1847) (sympatric species with the yellow clam), while young, occupy preferably the upper region of the mesolitoral, and when adult, dislocate to the swash zone. For D. hanleyanus, it was observed that this movement is related to the growth of the animal, where, as they develop, the specimens dislocate to the lower region of the swash zone (Gil and Thomé, 2001). For other species of the gender Donax (Linnaeus, 1758), such as D. trunculus (Linnaeus, 1758) and D. denticulatus (Linnaeus, 1758), the segregation by size is given in a similar way to D. hanleyanus (McLachlan et al., 1996), as well as for many macroinvertebrate species that populate the sandy beaches (McLachlan and Jaramillo, 1995).

Olivier et al. (1971) and Defeo et al. (1992), studying M. mactroides at Mar Azul beach (Argentina) and at Barra del Chuy (Uruguay), respectively, mention that during the recruitment process, the new generations (recruits) tend to be in smaller numbers. In the zones where there is a larger concentration of adults, because, besides the competition for space, the destruction of the larva can occur, caused by the plankton filtering mechanism of the adults, as well as the probable intraspecific competition for food.

The segregation by size observed in this study appears to concur, in part, to what was cited by the above mentioned authors. It is believed that the segregation between recruit and adult individuals can be connected to the larva filtering mechanism itself, according to Lima et al. (2000). They have observed that the density of adult specimens affects the process of recruitment/settling of the species and, as a consequence, the segregation strategy makes sense. Another factor to be considered is that these specimens, for being small and light, are easily transported to the regions above the average point of the swash zone, which can be easily observed at exposed sandy beaches.

The probable competition for space and for food between recruit, young and adult specimens seems not to exist, once the young specimens do not segregate from the others, as shown in this work, being that they occur along with the others. This could be explained by the depth difference in which they are buried in the substratum, for the depth in which they are buried is directly proportional to their length (Coscarón, 1959).

The vertical migration movement towards the points close to the lower shore ( $\mathrm{P}-2$ and $\mathrm{P}-1)$ during winter and spring, mainly by adult and also young individuals, resembles in some aspects what was observed by Coscarón (1959) and Olivier and Penchaszadeh (1968) at the beaches of the province of Buenos Aires (Argentina), where they mention that the vertical distribution of the agglomerates formed by the yellow clam occurs according to the seasons of the year, where the specimens migrate from the upper mesolitoral, in the summer, to the floor levels of the lower shore, in the end of the winter and beginning of spring, being that the recruits spread through the tide line throughout the year. Fiori et al. (2004), studying the species in Monte Hermoso (Argentina), comments that during the winter, the majority of the population is found in the intertidal zone, which was a constant throughout this study, because the species is characterized by distributing itself in the intertidal zone, varying only in abundance within the different areas that comprehend such zone. Olivier et al. (1971) and Defeo et al. (1992) mention that the migration of the yellow clam to the limits between the lower mesolitoral and the lower shore occurs by occasion of a probable scarcity of food during the winter, when the animals reduce metabolic activity, in an attempt to avoid the stress provoked by extremely cold temperatures. On this account, Brazeiro and Defeo (1996) point out two factors as determinants in the variability of the zoning process of the organisms in temperate beaches with microtidal regimes: the change of position of the upper limit of the swash zone and the variations in water and air temperatures.

The hypothesis which is raised here suggests that the seasonal migration by these individuals which present an average length of $38.33 \mathrm{~mm}( \pm 1.35)$ (considering young individuals) and of $50.96 \mathrm{~mm}( \pm 1.79)$ (disconsidering young individuals), may be associated to the reproduction period of the species, once that it was in the end of the winter and beginning of spring (August and September) that the highest recruitment peak of the species was observed (Figure 11). Under another perspective, the result of the covariance analysis confirms this, for the seasons of the year of lowest length average (winter: $24.15 \mathrm{~mm}$; spring: $13.94 \mathrm{~mm}$ ) were those in which the highest recruitment peak of the species occurred (end of winter and spring), associated with the low temperatures.

Coscarón (1959) mentions that the individuals with sizes superior to $35 \mathrm{~mm}$ can be mature; Olivier et al. (1971) found maturing specimens with lengths between 33 and $55 \mathrm{~mm}$, being that the estimated interval for the first maturing is between 42,12 and 44, $25 \mathrm{~mm}$ of length; Masello and Defeo (1986) and Masello (1987) cite that the first maturing is given between 41,57 and $44,11 \mathrm{~mm}$ of length, being that this process can occur before or 
after this interval (36 and $48 \mathrm{~mm}$ ). After the maturing of the gonads occurs, the specimens need to migrate to the zones close to the sea in order to liberate the gametes (Coscarón, 1959). This hypothesis is verified by the movement of the adult specimens $(<43 \mathrm{~mm})$ during winter and spring towards P-2 and P-1 (Figures 9a and b). For this reason, the results found in this study seem not to verify with what was mentioned by Olivier et al. (1971) and Defeo et al. (1992) about the seasonal migration of the yellow clam, and it seems to verify, in part, what is mentioned by Brazeiro and Defeo (1996), once that, for the majority of benthic invertebrates and for species that inhabit sandy beaches, seasonal zonation and its migration processes are related to temperature variability, which directly influences the unleashing of the reproductive process of these species. The results found by Defeo et al. (1992) and Olivier et al. (1971) must also be considered, because each population, in different locations, tends to respond in a different manner facing the wide variability of abiotic factors. This can be perceived through the differences between the water temperatures in these works, being that the difference between minimum and maximum temperatures observed here was of $10{ }^{\circ} \mathrm{C}$, and, in the study of Defeo et al. (1992), the difference between temperatures was of $14^{\circ} \mathrm{C}$. Besides this, the temperature differences between Brazilian, Uruguayan and Argentinean coast waters are known, reason for which the migration to the zones close to the sea, in this study, cannot be related to the stress occasioned by extremely cold temperatures or by the scarcity of food, but can be related, as inferred, with the reproduction period of the species. The same occurs with its sympatric species, where Gil (2004) verified that the movement presented by $D$. hanleyanus towards the lower region of the swash zone is related to the gonad maturing process and consequent reproductive process, which strengthens our results, being that the strategies and solutions found by these two species facing an environment as dynamic as the exposed sandy beaches may present similarities

Considering the differences encountered in works that had as an objective the investigation of the vertical distribution of yellow clam, it is pointed out that the development of these works over a minimum period of one year is very important (Brazeiro and Defeo, 1996) or, if possible, with durations longer than the ones mentioned by the authors, being that climate conditions, nowadays, vary drastically from one year to another and, this way, the zonation of $M$. mactroides could be monitored over the years, in function of the abiotic factors involved, from one period to another.

\section{References}

BORZONE, CA. and SOUZA, JRB., 1997. Estrutura da macrofauna bentônica no supra, meso e infralitoral de uma praia arenosa do sul do Brasil. Oecologia Brasiliensis, vol. 3, p. 197-212.
BRAZEIRO, A. and DEFEO, O., 1996. Macroinfauna zonation in microtidal sandy beaches: is it possible to identify patterns in such variable environments? Estuar. cstl and Shelf Sci., vol. 42, no. 4, p. 523-536.

COSCARÓN, S., 1959. La almeja amarilla (Mesodesma mactroides, Deshayes) de la costa de la Provincia de Buenos Aires. Agro. Publ. Tec., vol. 1, no. 3, p. 1-66.

DAHL, E., 1952. Some aspects of the ecology and zonation of the fauna on sandy beaches. Oikos, vol. 4, p. 1-27.

DEFEO, O., 1998. Testing hypotheses on recruitment, growth, and mortality in exploited bivalves: an experimental perspective. In Proceedings of the North Pacific Symposium on Invertebrate Stock Assessment and Management. Can. Spec. Publ. Fish. Aquat. Sci., vol. 125, p. 257-254.

DEFEO, O., ORTIZ, E. and CASTILLA, JC., 1992. Growth, mortality and recruitment of the yellow clam Mesodesma mactroides on Uruguayan beaches. Mar. Biol., vol. 114, no. 3 , p. 429-437.

ESCOFET, A., GIANUCA, N., MTYA, S. and SCARABINO, V., 1979. Playas arenosas del atlantico sudoccidental entre $\operatorname{los} 29^{\circ}$ y $43^{\circ}$ LS.: consideraciones generales y esquema biocenologico. In Memorias del Seminario sobre Ecología Bentónica y Sedimentación de la Plataforma Continental del Atlántico Sur, UNESCO, p. 245-258.

FIORI, MS., CAZZANIGA, NJ., and ESTEBENET, AL., 2004. Winter distribution, density and size of Mesodesma mactroides (Bivalvia, Mactracea) in Monte Hermoso beach (Argentina). Braz. J. Oceanogr, vol. 52, no. 1, p. 01-09.

GIANUCA, NM., 1983. A preliminary account of the ecology of sandy beaches in Southern Brazil. In Sandy beaches as ecosystems. McLACHLAN, A. and ERASMUS, T. (eds). p. 413-419.

GIANUCA, NM., 1985. The ecology of a sandy beach in Southern Brazil. University of Southampton, Southampton, 330p. (Doctoral Thesis).

GIANUCA, NM., 1987. Zonação e produção nas praias arenosas do litoral sul e sudeste do Brasil: síntese dos conhecimentos. In: Simpósio sobre ecossistemas da costa Sul e Sudeste Brasileiro. Academia de Ciências de São Paulo, vol. 1, p. 313-332.

GIL, GM. and THOMÉ, JW., 2000. Distribuição vertical de moluscos marinhos em uma praia arenosa exposta do Estado do Rio Grande do Sul, Brasil. Com. Mus. Ciênc. Tecnol. PUCRS, Sér. Zool., vol. 13, p. 147-157.

GIL, GM. and THOMÉ, JW., 2001. Distribuição vertical de Donax hanleyanus (Mollusca, Bivalvia, Donacidae) em praia arenosa do Rio Grande do Sul. Biociências, vol. 9, no. 1, p. 33-44.

GIL, GM., 2004. Zonação por tamanho, estabilização da forma da concha e atividade reprodutiva em espécies do gênero Donax (Mollusca, Bivalvia, Donacidae). (Tese de Doutorado) Pontifícia Universidade Católica do Rio Grande do Sul, Porto Alegre. $190 \mathrm{p}$.

LIMA, M., BRAZEIRO, A. and DEFEO, O., 2000. Population dynamics of the yellow clam Mesodesma mactroides: recruitment variability, density-dependence and stochastic processes. Mar. Ecol. Prog. Ser, vol. 207, p. 97-108.

MASELLO, A., 1987. Consideraciones sobre crecimiento y biología reprodutiva de la almeja amarilla Mesodesma 
mactroides (Deshayes, 1854). (Tesis para optar a la Licenciatura en Oceanografia Biológica). Montevideo, 123 p.

MASELLO, A. and DEFEO, O., 1986. Determinación de la longitud de primera madurez sexual en Mesodesma mactroides (DESHAYES, 1854). Comun. Soc. Malacol. Urug, vol. 6, no. 51 , p. $387-395$

McLACHLAN, A., 1990. Dissipative beaches and macrofauna communities on exposed intertidal sands. J. Coast. Res., vol. 6, no. 1 , p. $57-72$

McLACHLAN, A. and JARAMILLO, E., 1995. Zonation on sandy beaches. Oceanography and Marine Biology: an annual review, vol. 33, p. 305-335.

McLACHLAN, A., DUNGAN, JE., DEFEO, O., ANSELL, AD., HUBBARD, DM., JARAMILLO, E. and PENCHASZADEH, PE., 1996. Beach clam fisheries. Oceanography and Marine biology: an Annual Review, vol. 34, p. 163-232.

OLIVIER, SR. and PENCHASZADEH, PE., 1968. Evaluación de los efectivos de almeja amarilla (Mesodesma mactroides DESH. 1854) en las costas de la provincia de Buenos Aires. Proyeto Desar. Pesquero, FAO Ser. Inf. Tec., vol. 8, p. 1-10.

OLIVIER, SR., CAPEZZANI, DAA., CARRETO, JI., CHRISTIANSEN, HE., MORENO, VJ., MORENO, JEA, and PENCHASZADEH, PE., 1971. Estructura de la comunidad, dinámica de la población y biología de la almeja amarilla (Mesodesma mactroides Desh., 1854) en Mar Azul (Pdo. de
Gral. Madariaga, Bs. As., Argentina). Proy. Desarr. Pesq. FAO, Ser. Inf. Tecn. Publ., vol. 27, p. 1-90.

RIOS, EC., 1994. Seashells of Brazil. Rio Grande: FURG. 2 ed. $386 \mathrm{p}$.

SALVAT, B., 1964. Les conditions hydrodynamiques interstitielles des sediments meubles intertidaux et la repartition verticale de la faune endogée. Cahiers de Recherche de la Academie de Science de Paris, vol. 259, p. 43-56.

SILVEIRA, EF., 1998. Dinâmica populacional de Emerita brasiliensis Schmitt, 1935 em praia arenosa do litoral sul do Brasil (Crustácea, Decapoda, Hippidae). (Dissertação de Mestrado) - Pontifícia Universidade Católica do Rio Grande do Sul, Porto Alegre. 76 p.

SOKAL, RR., ROLHF, FJ., 1997. Biometry. 3 ed. New York: FREEMAN, WH. $887 \mathrm{p}$.

TOMAZELLI, LJ. and VILLWOCK, J., 1992. Considerações sobre o ambiente praial e a deriva litorânea de sedimentos ao longo do litoral norte do Rio Grande do Sul, Brasil. Pesqui. Geocienc., vol. 19, no. 1, p. 3-12.

VILLWOCK, JA., 1987. Os paleoambientes da Província Costeira do Rio Grande do Sul e a possível ocorrência de antigos manguezais na costa do sul do Brasil. In Anais III Simpósio sobre Ecossistemas da Costa Brasileira - Síntese dos Conhecimentos. Publ. ACIESP, vol. 1, p. 132-137.

ZAR, JH., 1999. Biostatistical Analysis. 4 ed. New Jersey: Prentice Hall. 663 p. 